\title{
Biosorption of Mn (II) by Spirogyra verrucosa collected from Manganese Mine Water
}

\author{
S. R. Bansod ${ }^{1 *}$ and P. B. Nandkar ${ }^{2,3}$ \\ ${ }^{1}$ Department of Botany, Shri Shivaji Arts, Commerce \& Science College, Akola, Dist. Akola (M.S.), India. \\ ${ }^{2}$ Department of Botany, Rashtrasant Tukadoji Maharaj Nagpur University, Nagpur (M.S.)India.
}

Article history

Received: 24 June 2016

Accepted: 25 July 2016

Published: 3 August 2016

(c) Bansod and Nandkar (2016)

Editor

K K Sabu

Publisher

Horizon e-Publishing Group

Corresponding Author

S. R. Bansod

$\square_{\text {shailesh.bansod@gmail.com }}$

${ }^{3}$ Present address: Department of Botany, R. T. M. Nagpur

University, Nagpur (M.S.), India

\begin{abstract}
Mining industries frequently generates acid mine drainage (AMD) either by its operating or abandoned mines which are often characterized by an elevated levels of certain heavy metals, sulphate, low $\mathrm{pH}$ and some other toxic impurities in mine water creates environmental and ecological problems. Present study planned to suggest role of alga Spirogyra verrucosa in Manganese (Mn) removal by biosorption process from the mine water of Manganese mines of Nagpur District, Vidarbha Region, Maharashtra. The biosorption of Mn(II) ions from aqueous solution by using dead green algal (S.verrucosa) biomass was investigated by studying effect of $\mathrm{pH}$, temperature, quantity of biosorbent, contact time as well as initial metal ion concentration. The optimized values obtained with respect to these parameters clearly indicates that $\mathrm{pH} 5$, temperature $30^{\circ} \mathrm{C}$, biosorbent quantity $1.0 \mathrm{gm} / \mathrm{l}$, contact time $120 \mathrm{~min}$. and initial metal ion concentration $50 \mathrm{mg} / \mathrm{l}$ were the basic requirement for the biosorption of $\mathrm{Mn}$ (II) ions by dead algal biomass. Also, the biosorption kinetic and isotherm modeling applied to the equilibrium data for biosorption of $\mathrm{Mn}$ (II) ions onto alga reveals the fitness of the pseudo-second-order rate expression $\left(\mathrm{R}^{2}=0.994\right)$ as well as the suitability of Langmuir $\left(\mathrm{R}^{2}=0.859\right)$ and Freundlich $\left(\mathrm{R}^{2}=0.761\right)$ isotherm models with an indication of the applicability of this metal ion-dried algal system for removal of $\mathrm{Mn}$ (II) ions in a monolayer biosorption as well as heterogenous surface conditions. However, comparatively biosorption equilibrium was better described by Langmuir isotherm model with monolayer biosorption capacity of S.verrucosa biomass $21.80 \mathrm{mg} / \mathrm{g}$. Also, the maximum removal $40.66 \mathrm{mg} / \mathrm{g}(80.20 \%)$ of $\mathrm{Mn}$ (II) ion by alga under optimized conditions promises the potential use in mine water treatment technology.
\end{abstract}

Keywords

AMD; Green alga; Spirogyra verrucosa; Manganese(II); Biosorption; Kinetics; Isotherm modeling

Bansod, S. R. and P. B. Nandkar. 2016. Biosorption of Mn (II) by Spirogyra verrucosa collected from Manganese Mine Water. Plant Science Today 3(3): 282-292. http://dx.doi.org/10.14719/pst.2016.3.3.244

\section{Introduction}

With the progress of industrialization and human activities, the threat of the discharge of waste and wastewater containing heavy metals to environment by various industries has now tremendously increased (Volesky, 2001). Mining industries frequently generates acid mine drainage (AMD) either by its operating or abandoned mines which are often characterized by an elevated levels of certain heavy metals, sulphate, low $\mathrm{pH}$ and some other toxic impurities in mine water (Modis et al.,
1998) and can cause pollution of surface and ground water as well as surrounding land if not controlled in due course of time.

Environmental contamination due to heavy metals leads to the phenomenon of accumulation in food chain and becomes a permanent burden on ecosystems (Bailey et al., 1999) causing serious hazard to human health and other forms of life. However relevant national and international standards and guidelines have been prepared by various agencies for the purpose of environmental 


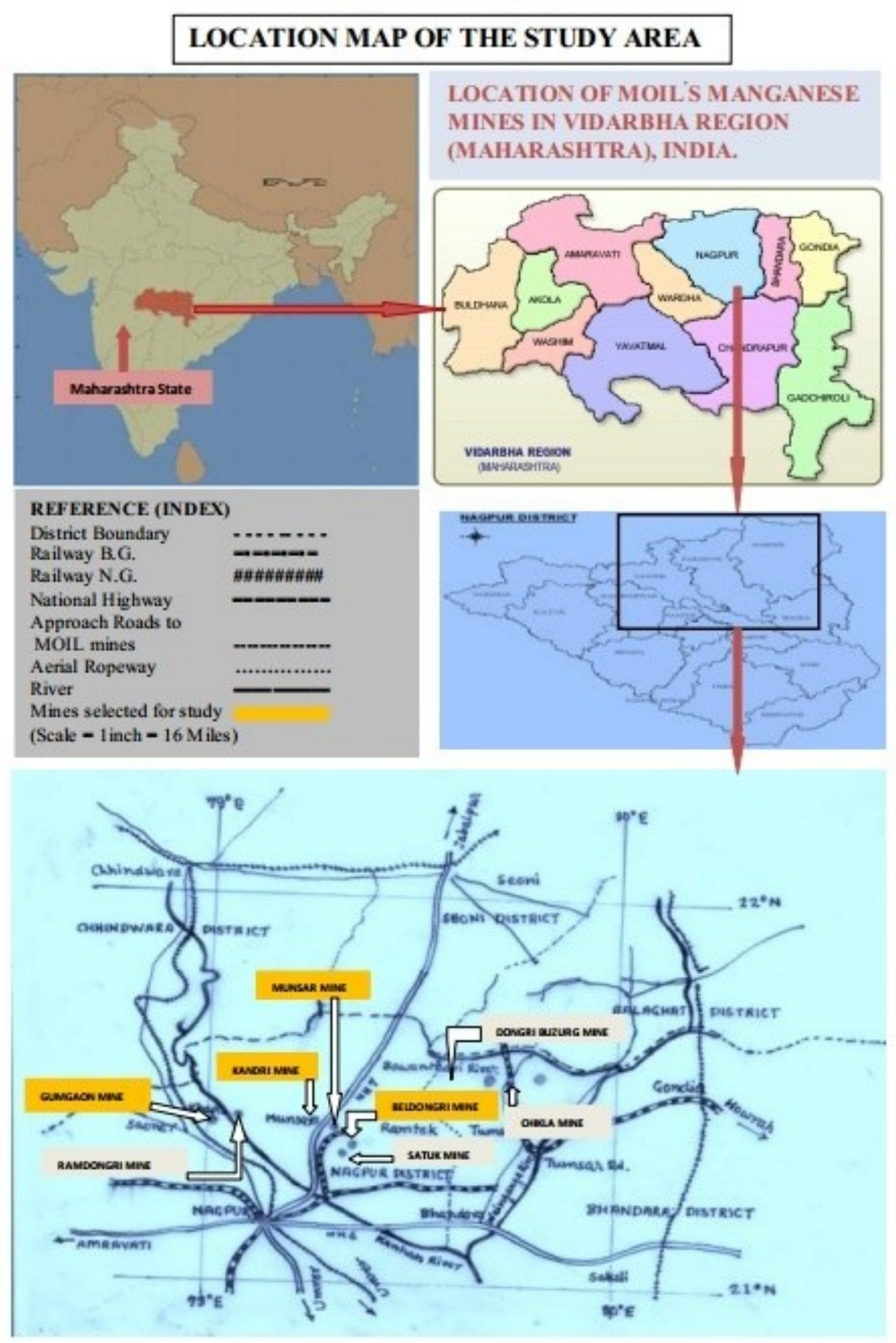

Map 1. Location map of the study area (Source: www.google.com, www.moil.nic.in)

protection with respect to the metal bearing effluents discharge in to water bodies and natural streams. Different technologies on assessment of acid mine drainage were proposed by several researcher (Moreno et al., 2001; Mohan and Chander, 2001; Brenner, 2001 and Saha et al., 2002; Morgan et al., 2004).

Conventional technologies currently available for removal of heavy metals are quite expensive and not much effective (Volesky, 2001) and also generates toxic byproducts (Aksu et.al., 1998) questioning their environmental friendly applications as well as techno-economic feasibility (Sandau et al., 1996). Therefore efficient, inexpensive and environment friendly technologies are in urgent need to control heavy metal contamination in wastewaters at discharge point to acceptable or permissible level (Matheickal and Yu, 1996). Biosorption seems to be a novel, competitive, effective and cheap approach to fulfill the requirements (Volesky, 2001) and has certain advantages than the conventional type of technologies used so far (Kratochvil and Volesky, 1998; Ahalya et al., 2003). Many microorganisms like algae, bacteria, fungi and yeast has been used in biosorption process to remove metal ions because of their remarkable advantages over conventional methods (Arica et al., 2001) and capability to bind with metal ions from aqueous solutions as well (Dursun, 2006; Wang and Chen, 2006; Volesky, 2007).

The present investigation was undertaken to assess and optimize Mn (II) sorption capacity of alga Spirogyra verrucosa (Guiry and Guiry, 2014) 


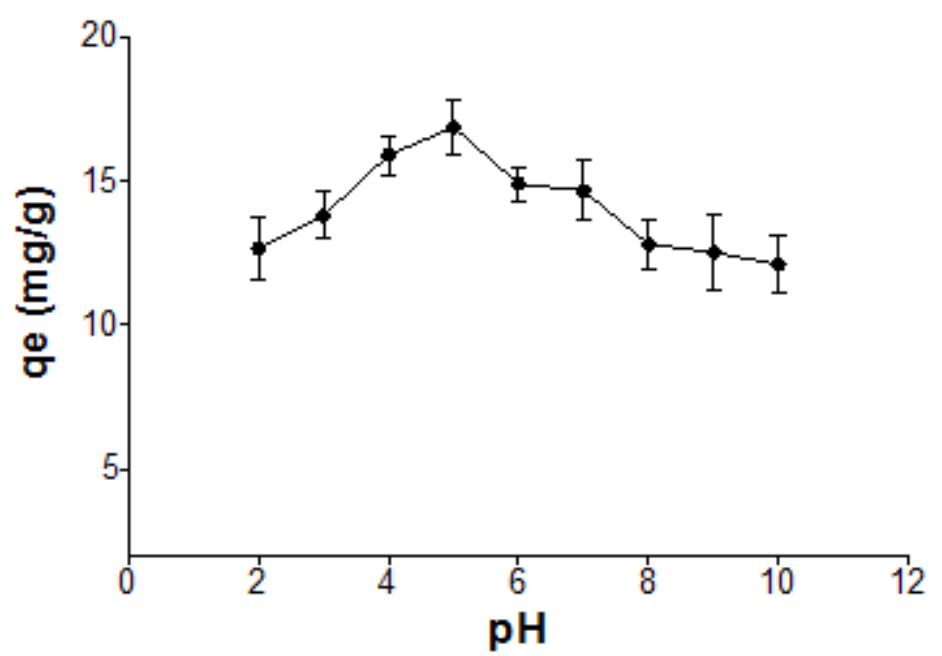

Fig: 1.Effect of $\mathrm{pH}$ on equilibrium Mn (II) sorption capacity of Spirogyra verrucosa $(n=3 \pm S D)$.

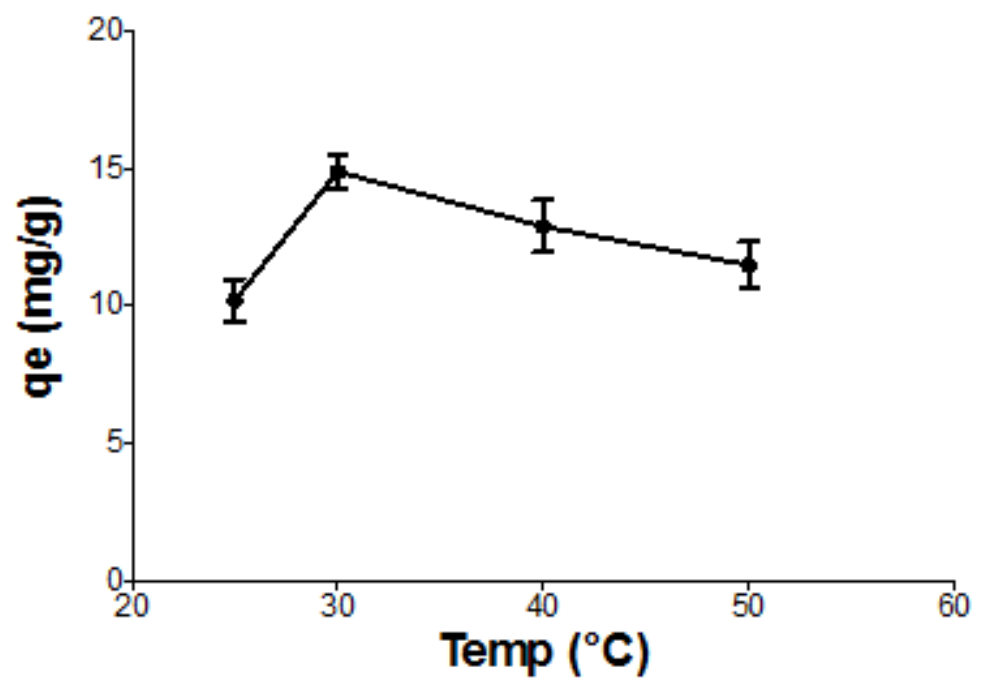

Fig.: 2. Effect of temperature on equilibrium Mn (II) sorption capacity of Spirogyra verrucosa.Data points are mean of three independent experiments (Mean $\pm \mathrm{SD}$ ).

collected from Mn contaminated (Bansod and Nandkar, 2015) Manganese mine water. However, many algal systems have been used in order to remove metal ions from different contaminated sites although there is lack of information available on the biosorption of metal ions by algal biomass from Manganese mine water. Optimization of $\mathrm{pH}$, contact time, temperature, biosorbent quantity and initial metal ion concentration of Mn(II) sorption capacity of alga was studied. Suitability of both Langmuir and Freundlich adsorption isotherm for equilibrium isotherm modeling between unadsorbed and adsorbed Mn(II) ions was studied. Kinetic study was also applied to the Mn(II) ion biosorption data for the validity of rate expression model. Findings of the investigation would be helpful during planning and strategy development in designing mine water treatment system for the mining sites in near future.

\section{Materials and Methods}

\subsection{Collection of algal material}

Four Manganese mines (Kandri, Mansar, Beldongari and Gumgaon) of MOIL (Manganese Ore India Limited) Nagpur District, Vidarbha Region, Maharashtra, India (Map 1) were selected and surveyed for algal material collection from open pit pond mine water. In present investigation 


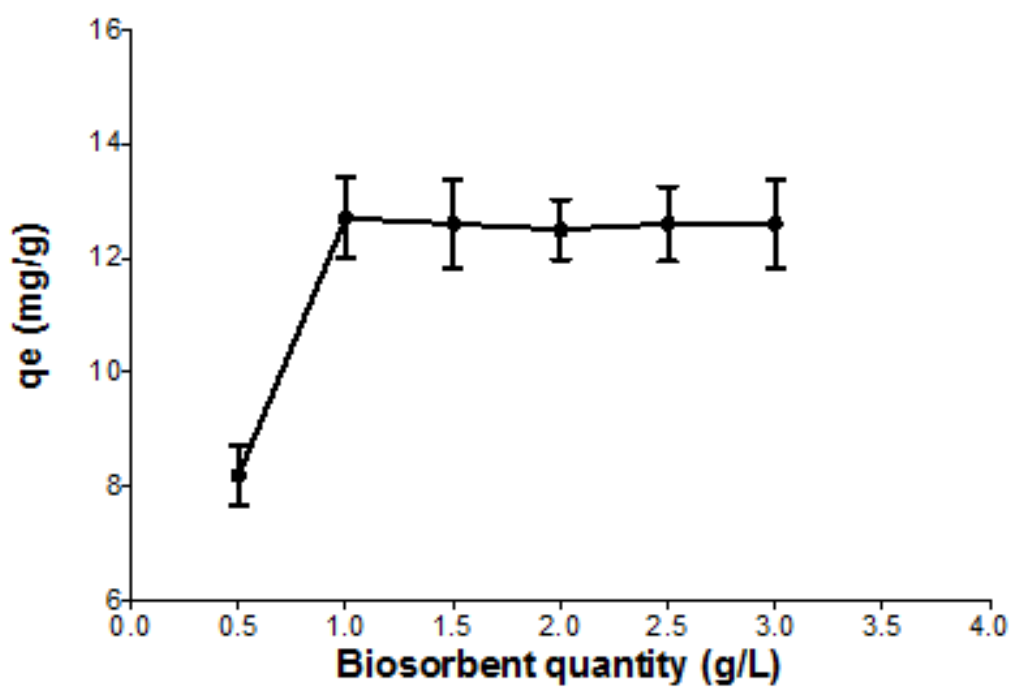

Fig. 3. Effect of biosorbent quantity on equilibrium Mn (II) sorption capacity of Spirogyra verrucosa $(\mathrm{n}=\mathbf{3} \pm \mathrm{SD})$.

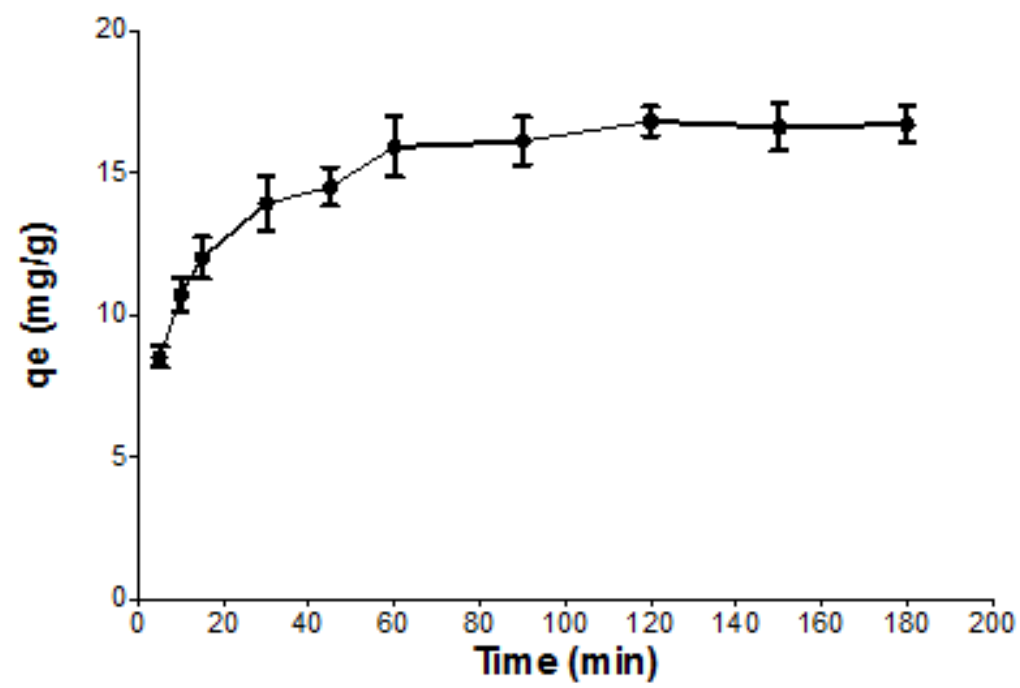

Fig. 4. Effect of contact time on equilibrium Mn (II) sorption capacity of Spirogyra verrucosa $(\mathrm{n}=\mathbf{3} \pm \mathrm{SD})$.

alga $S$. verrucosa was found to be present abundantly forming mats on the mine water which contains an elevated level of Manganese concentration and hence used as a biosorbent.

\subsection{Preparation of biosorbent}

The harvested algal biomass from mine water was initially washed thoroughly with distilled water to remove all the extraneous material attached to it and placed on a filter paper/ blotting paper to reduce the water content before treating the biomass with $0.02 \mathrm{M} \mathrm{HNO}_{3}$. Then it was dried overnight at $50^{\circ} \mathrm{C}$ until a constant weight was obtained and the final weight of the biosorbent was recorded. The biosorbent were then crushed and passed through a $300 \mathrm{~nm}$ sieve to attain uniform particle size and used for further studies.

\subsection{Preparation of synthetic solution}

Synthetic stock solution of Manganese was prepared by dissolving 3.076 grams of $\mathrm{MnSO}_{4}$ $7 \mathrm{H}_{2} \mathrm{O}$ (Analytical grade) in $100 \mathrm{ml}$ of double distilled water to obtain concentration of 1000 $\mathrm{mg} / \mathrm{l}$ as a stock solution and serial dilutions from of this stock solution were prepared to obtain 10 , $20,30,40,50,60,70,80,90$ and $100 \mathrm{mg} / \mathrm{l}$ concentration of Mn(II) ion solution. The desired $\mathrm{pH}$ were maintained by using buffer solutions (KCl-HCl buffer for $\mathrm{pH} \mathrm{2,} \mathrm{citric} \mathrm{acid-} \mathrm{sodium}$ 


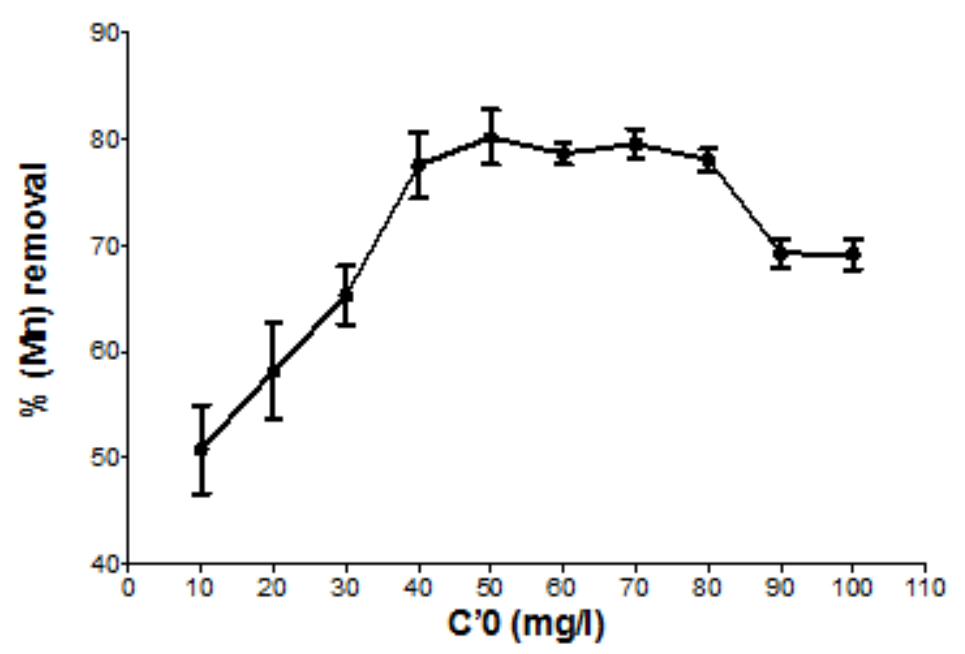

Fig. 5. Equilibrium adsorption quantities and $\%$ removal of $\mathrm{Mn}$ (II) ions at different concentration by Spirogyra verrucosa $(n=3 \pm S D)$.

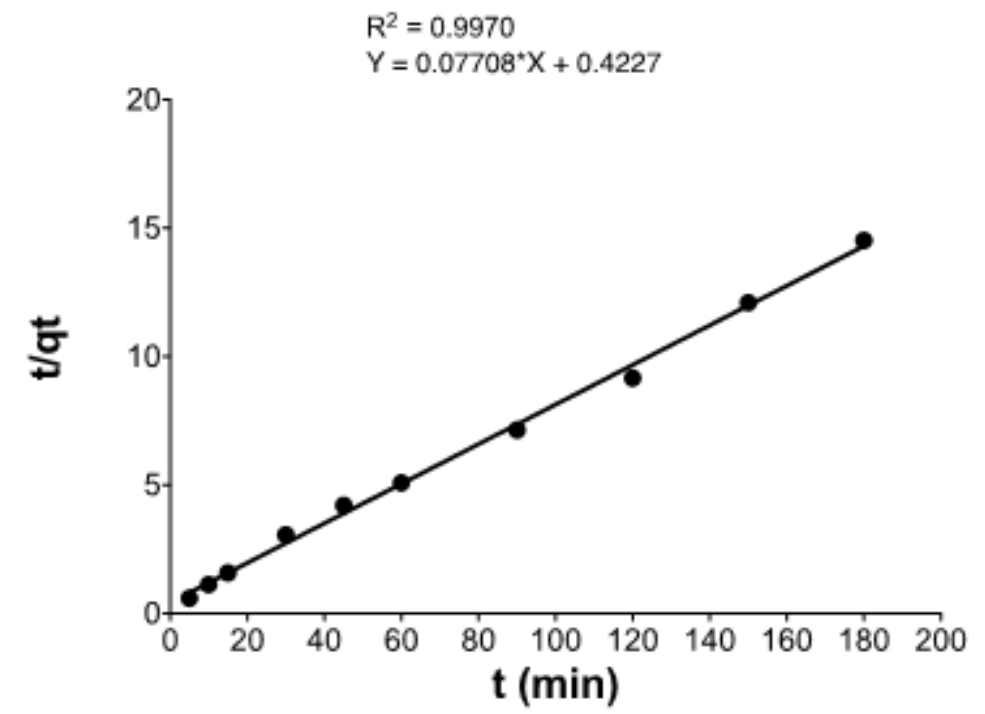

Fig. 6. Pseudo-second order kinetic plot of biosorption of Mn (II) ions onto Spirogyra verrucosa.

citrate buffer for pH 3-5, $\mathrm{Na}_{2} \mathrm{HPO}_{4}-\mathrm{NaH}_{2} \mathrm{PO}_{4}$ buffer for $\mathrm{pH}$ 6-8 and glycine- $\mathrm{NaOH}$ buffer for $\mathrm{pH}$ 9-10) in all experiments.

\subsection{Batch mode studies}

The experiments for the batch mode studies were carried out in $250 \mathrm{ml}$ Erlenmeyer flasks with dry algal biomass of $0.5 \mathrm{~g} / 100 \mathrm{ml}$ aqueous solution. The flasks filled with Mn(II) ion concentrations ranging from $10 \mathrm{mg} / \mathrm{l}$ to $100 \mathrm{mg} / \mathrm{l}$ were kept at $25^{\circ} \mathrm{C}$ on a rotary shaker at 200rpm. Evaluation of the maximum biosorption capacity of the alga was carried out on optimization of $\mathrm{pH}(2-10)$, temperature $\left(25-50^{\circ} \mathrm{C}\right)$, contact time (5-180 min.) by using $100 \mathrm{ml}$ of $20 \mathrm{mg} / \mathrm{l}$ concentration of $\mathrm{Mn}$ (II) metal ion with an algal biomass dose of $0.5 \mathrm{~g}$ (dry weight) per flask except for optimization of biosorbent quantity and initial metal ion concentration the range of algal dose (0.5-3 g) and initial metal ion concentration $(10-100 \mathrm{mg} / \mathrm{l})$ were used respectively. Blanks were also considered for each treatment in the experiments.

\subsection{Metal Analysis}

All the samples were tested for metal ion concentration by using Atomic Absorption Spectrometer (AAS) at Department of Chemistry, Laxminarayan Institute of Technology, Rashtrasant Tukadoji Maharaj Nagpur University, Nagpur. 
Table 1. Mean ( $n=3 \pm$ SD) of equilibrium biosorption quantities and \% removal of Mn (II) ions at different concentration by the algal biomass Spirogyra verrucosa.

\begin{tabular}{llcc}
\hline & & & Spirogyra verrucosa \\
\hline $\mathrm{C}^{\prime}{ }_{0}(\mathrm{mg} / \mathrm{l})$ & $\mathrm{C}_{0}(\mathrm{mg} / \mathrm{l})$ & $\mathrm{qe}(\mathrm{mg} / \mathrm{g})$ & \% removal \\
\hline 10 & $9.04 \pm 1.26$ & $4.59 \pm 0.65$ & $50.80 \pm 7.25$ \\
20 & $19.2 \pm 0.62$ & $11.17 \pm 1.51$ & $58.20 \pm 7.88$ \\
30 & $29.4 \pm 0.75$ & $19.19 \pm 1.40$ & $65.30 \pm 4.76$ \\
40 & $39.6 \pm 1.85$ & $30.72 \pm 2.16$ & $77.60 \pm 5.46$ \\
50 & $50.7 \pm 0.72$ & $40.66 \pm 2.26$ & $80.20 \pm 4.46$ \\
60 & $61.3 \pm 1.57$ & $48.24 \pm 1.08$ & $78.70 \pm 1.76$ \\
70 & $69.6 \pm 2.10$ & $55.40 \pm 1.73$ & $79.60 \pm 2.49$ \\
80 & $78.4 \pm 1.34$ & $61.23 \pm 1.47$ & $78.10 \pm 1.88$ \\
90 & $89.2 \pm 1.05$ & $61.81 \pm 2.00$ & $69.30 \pm 2.24$ \\
100 & $102 \pm 3.00$ & $70.58 \pm 2.55$ & $69.20 \pm 2.50$ \\
\hline
\end{tabular}

$\mathrm{C}_{0}=$ Initial calculated $\mathrm{Mn}(\mathrm{II}), \mathrm{C}_{0}=$ Initial estimated $\mathrm{Mn}(\mathrm{II})$

Table.2. Pseudo-second order kinetic constants for the biosorption of Mn (II) ions by the algal biomass Spirogyra verrucosa.

\begin{tabular}{lllll}
\hline Biosorbent & \multicolumn{3}{c}{ Mn(II) } \\
\hline & $\begin{array}{l}\mathrm{q}_{\text {eq }} \text { Exp. } \\
(\mathrm{mg} / \mathrm{g})\end{array}$ & $\begin{array}{l}\mathrm{q}_{\text {eq }} \text { Cal. } \\
(\mathrm{mg} / \mathrm{g})\end{array}$ & $\begin{array}{l}\mathrm{K}_{2} \\
(\mathrm{~g} / \mathrm{mg} \text { min. })\end{array}$ & $\mathrm{R}^{2}$ \\
\hline Spirogyra verrucosa & 14.9 & 14.49 & 0.010 & 0.994 \\
\hline
\end{tabular}

Table.3.Langmuir and Freundlich Isotherms' constants for the biosorption of Mn (II) ions by the algal biomass Spirogyra verrucosa.

\begin{tabular}{|c|c|c|c|c|c|c|}
\hline \multirow[t]{3}{*}{ Biosorbent } & \multicolumn{6}{|c|}{ Mn(II) } \\
\hline & \multicolumn{3}{|c|}{ Langmuir parameters } & \multicolumn{3}{|c|}{ Freundlich parameters } \\
\hline & $\begin{array}{l}q_{\max } \\
(\mathrm{mg} / \mathrm{g})\end{array}$ & $\begin{array}{l}\mathrm{b} \\
(\mathrm{L} / \mathrm{mg})\end{array}$ & $\mathrm{R}^{2}$ & $\mathrm{n}$ & $\mathrm{K}_{\mathrm{f}}$ & $\mathrm{R}^{2}$ \\
\hline Spirogyra verrucosa & 21.80 & 48.52 & 0.859 & 1.75 & 89.94 & 0.761 \\
\hline
\end{tabular}

\subsection{Mathematical Modeling and Interpretation of Data}

The data collected as a result of biosorption studies were tested by conventionally used Langmuir and Freundlich isotherms for adsorption. In addition, kinetic examination was also carried out for the validity of rate expression model.

\subsection{Statistical analysis}

The data obtained in triplicate were analyzed by SPSS statistical package (Window version 17) and Microsoft software Excel 2007 and represented as mean values with standard deviation in figures and tables.

\section{Results and discussion}

Biosorption of Mn(II) was studied by considering the importance of $\mathrm{pH}$, temperature, contact time, biosorbent quantity and initial metal ion concentration as an influencing factors in the process. The biosorption data were fitted to different isotherms and kinetic models.

\subsection{Effect of $p H$ on $M n(I I)$ biosorption}

The removal of Mn(II) ions by alga was found to be $\mathrm{pH}$ dependent at an initial calculated metal ion concentration of $20 \mathrm{mg} / \mathrm{l}$. Acidic $\mathrm{pH}$ range (4-6) was favored by alga for equilibrium Mn(II) sorption and maximum biosorption $16.8 \mathrm{mg} / \mathrm{g}$ was recorded at pH 5.0 (Fig. 1). Decrease in biosorption of Mn(II) ions by alga was observed at increased $\mathrm{pH}$ values. However, not such variations were noted in Mn(II) concentration of blanks readings (without alga) as a control.

Biosorption of metal ions have been reported $\mathrm{pH}$ dependent in several studies (Sheng et al., 2004, Romera et al., 2006). Maximum biosorption of metal ions at low pH range (4-6) seems to be contributed by positively charged algal surface and generation of isoelectric point for algal biomass at pH 5.0 (Crist, et al., 1981) as well as 


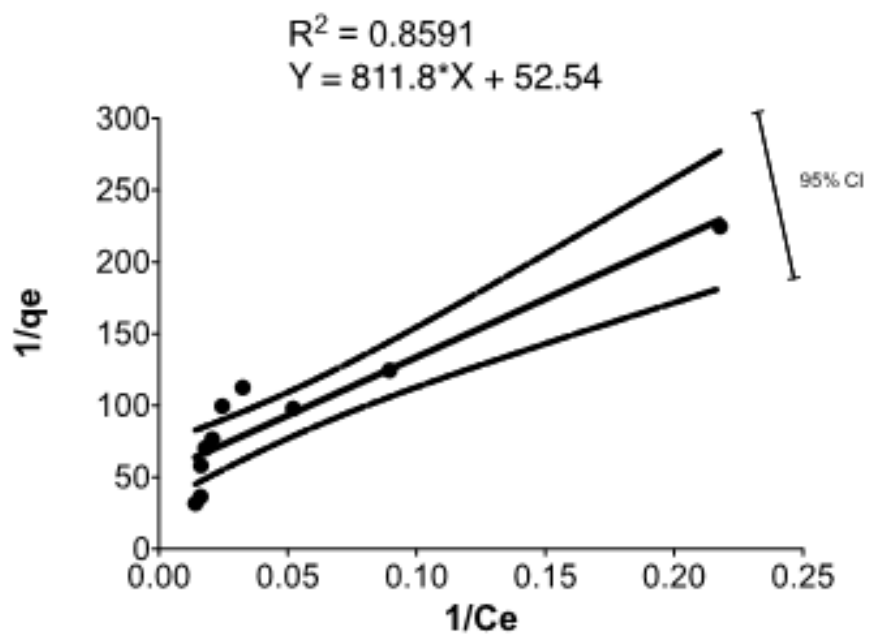

Fig. 7. Langmuir adsorption isotherm for biosorption of Mn (II) ion onto Spirogyra verrucosa. Solid line shows the linear relationship between the mass of adsorbate (Mn ) adsorbed and ratio of amount of final adsorbate /total mass of adsorbate adsorbed. Dotted line showed the $95 \%$ confidence interval.

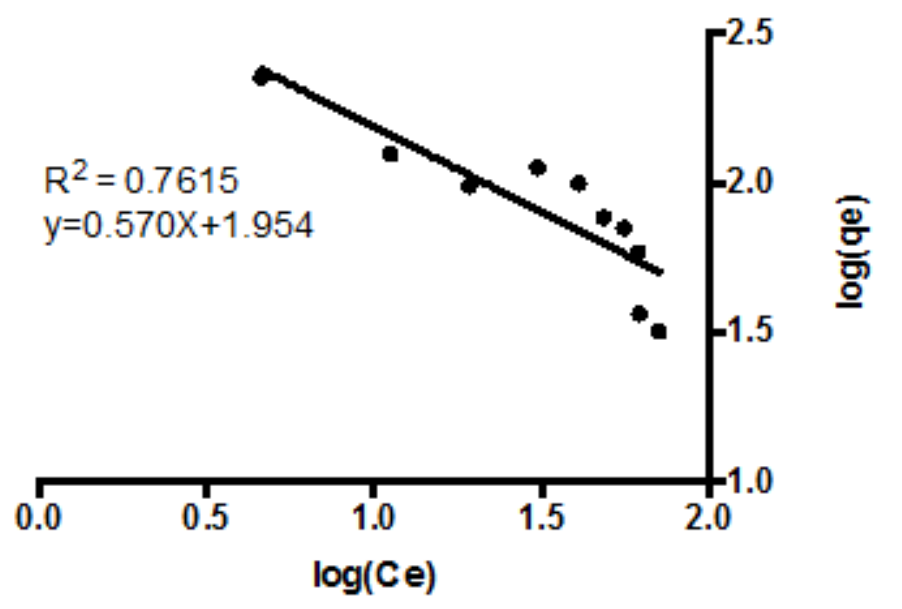

Fig. 8. Freundlich adsorption isotherm for biosorption of $\mathrm{Mn}$ (II) ion onto Spirogyra verrucosa

protonation of certain functional groups, binding sites surrounded with $\mathrm{H}^{+}$ions resulted in to attraction of metal ions towards algal surface at greater extent (Donmez and Aksu, 2002). However, there was decrease in biosorption at increased $\mathrm{pH}$ range (5-7) which might be due to precipitation of $\mathrm{Mn}(\mathrm{II})$ ions to $\mathrm{Mn}(\mathrm{OH})_{2}$ at higher $\mathrm{pH}$ level. Many algal species especially chlorophycean members have been reported for its biosorption capacities in the $\mathrm{pH}$ range 2.0 to 6.0 for metal ions (Han et al., 2006; Deng et al., 2007; Gupta and Rastogi, 2008).

\subsection{Effect of Temperature}

The temperature has been found to affect the biosorption. In present investigation extent of $\mathrm{Mn}$
(II) ion biosorption by $S$. verrucosa, has been recorded maximum $14.9 \mathrm{mg} / \mathrm{g}$ at $30^{\circ} \mathrm{C}$ (Fig. 2) and lower at 25,40 and $50^{\circ} \mathrm{C}$. The decreased adsorption at lower temperature can be due to shrinking of the surface whereas elevated temperatures can be attributed to exothermic characteristics of the biosorbent. Adsorption equilibrium alters in a very specific way because of temperature change either due to exothermic or endothermic nature of a process. The effect of temperature at a specific $\mathrm{pH}$ on the adsorption isotherm of metal ions by sorbent was explained by Shen and Duvnjak (2004). Similar findings were reported in other studies on removal of heavy metals also (Park et al., 2005 and Guzel et al., 2008). 


\subsection{Effect of Biosorbent Quantity}

The biosorption capacity and biomass concentration of biosorbents was found to be directly proportional to each other (Aydin et al., 2008, Dundar et al., 2008) but the amount adsorbed decreases per unit mass of biosorbents. In present investigation, better Mn(II) metal ion uptake $(12.7 \mathrm{mg} / \mathrm{g})$ was recorded at $1 \mathrm{gm} / \mathrm{l}$ concentration (Fig. 3) as compared to $0.5 \mathrm{gm} / \mathrm{l}, 2$ $\mathrm{gm} / \mathrm{l}, 2.5 \mathrm{gm} / \mathrm{l}$ and $3 \mathrm{gm} / \mathrm{l}$, per unit mass by the alga. Suitable reason for this type of trend might be due to the effect of a partial aggregation at increased concentration of biosorbent, which reduces availability of the effective surface area required for the biosorption of metal ions (Gupta et al., 2001). Increased biosorbent quantity also increases the availability of biosorption sites or functional groups (Tunali et al., 2006; Gupta and Rastogi, 2008).

\subsection{Effect of Contact Time}

Exposing biosorbent in terms of contact time for the sorbate is of great importance in the biosorption mechanism. In present investigation, equilibrium of the solution was generally achieved in $120 \mathrm{~min}$. (Fig. 4) by alga for the sorption of Mn (II) ions. Initially rapid adsorption of Mn(II) ions was recorded during the first 5 to 30 min. by algal biomass, slowing down considerably after the first $90 \mathrm{~min}$.. This was probably due to large number of vacant surface sites available at initial level for adsorption which might be unavailable or difficult to be occupied after some time because of forces among the solute molecules of the solid and bulk phase. Also dominance of intraparticle diffusion process over adsorption may have been result in the diminishing removal of metal ions with increasing time (Deo and Ali, 1993; Volesky, 2003). Similar finding on equilibrium time (120 min.) for sorption of metal ions was reported on green filamentous alga $S$. condensata (Onyancha et al., 2008).

\subsection{Effect of initial metal ion concentration}

The initial metal ion concentration plays an important role in the process of biosorption. In present investigation, Maximun biosorption $(40.66 \mathrm{mg} / \mathrm{g})$ and percent removal $(80.20 \%)$ was recorded at $50 \mathrm{mg} / \mathrm{l} \mathrm{Mn}(\mathrm{II})$ metal ion concentration by alga (Fig. 5 \& Table 1). The probable reason for this could be the availability of number of ions for competition at the binding sites at a particular concentration. But the biosorption of $\mathrm{Mn}$ (II) ion did not increases considerably above the concentration of $50 \mathrm{mg} / \mathrm{l}$ and the percent removal of metal ions remained approximately constant or even showed slight decrease representing saturation of all binding sites available for adsorption on algal surface beyond a particular concentration.

\subsection{Kinetic Studies}

In order to evaluate the kinetic parameters for the biosorption studies of Mn(II) ions by dead algal biomass the pseudo-second order kinetic model (Ho and McKay, 1999) was employed with optimized concentration of algal biomass (1gm/l), initial Mn(II) ion concentration (20 $\mathrm{mg} / \mathrm{l})$,temperature $\left(30^{\circ} \mathrm{C}\right)$ and time interval of 5,10 , 15, 30, 45, 60, 90, 120, 150, 180 min. (Fig. 4). Biosorption of Mn(II) ion increases with increasing contact time and equilibrium was attained at 120 min. indicates onset of desorption as there was no further increase in a biosorption observed with exceeded time.

According to the pseudo-second-order model the rate of occupation of biosorption sites is proportional to the square of the number of unoccupied sites. Determination of rate constants for biosorption of Mn(II) ions were done by using following equation (Ho and McKay, 1999).

$$
\frac{d q_{t}}{d}=K_{2}\left(q_{e-} q_{t}\right) 2
$$

(Eqn. 1)

Where, $K_{2}$ is equilibrium rate constant of pseudosecond order (g/mg min.), $q_{e}$ and $q_{t}$ are amount of metal ion sorbed $(\mathrm{mg} / \mathrm{g})$ at equilibrium and time $\mathrm{t}$ (min.), respectively. After being integrated and rearranged equation (Eqn. 1), following expression could be achieved:

$$
\frac{t}{q_{t}}=\frac{1}{K_{2} q_{e q}^{2}}+\frac{t}{q_{e q}}
$$

(Eqn. 2)

The rate constant values were calculated by plotting " $\mathrm{t} / \mathrm{qt}$ " versus " $\mathrm{t}$ ". Linear plot of " $\mathrm{t} / \mathrm{qt}$ " versus " $\mathrm{t}$ " for the pseudo-second-order model for the biosorption of $\mathrm{Mn}$ (II) ions on to the algal biomass at $20 \mathrm{mg} / \mathrm{l}$ initial Mn(II) ion concentration as shown in Fig. 6 and the values of $K_{2}, q_{e}$ and $\mathrm{R}^{2}$ calculated from the plot were represented in Table 2. There was a good agreement observed in calculated value of $q_{e}(14.49 \mathrm{mg} / \mathrm{g})$ and experimental value of $q_{e}(14.90 \mathrm{mg} / \mathrm{g})$, as indicated by very high coefficient of correlation $\left(\mathrm{R}^{2}\right)$ value 0.994 recommends the validity of pseudo-secondorder model to explain biosorption of Mn(II) ions by alga.

\subsection{Equilibrium Isotherm Modeling}

Langmuir model is based on an assumption that a monolayer sorption occurs at specific homogeneous sites of sorbate from the aqueous solution (Mashitah et. al., 2008). Therefore Langmuir isotherm was used to correlate the equilibrium data for the fitness of the isotherm. 
The Langmuir isotherm is represented by the following equation (Langmuir, 1918):

$$
q_{e}=q_{e} \cdot b \cdot C_{e}+\left(b+C_{e}\right)
$$

Where, $q_{e}$ is the equilibrium constant of sorbate ion on surface of the biosorbent $(\mathrm{mg} / \mathrm{g}), c_{e}$ is the equilibrium concentration of metal ion in solution ( $\mathrm{mg} / \mathrm{l})$ and $b$ is Langmuir's constant $(\mathrm{L} / \mathrm{mg})$. Linear plot of " $1 / q_{e}$ " versus " $1 / q_{e}$ " (Fig. 7) was obtained from the equilibrium data and the values of $q_{e}, c_{e}$ and $b$ were calculated from intercept and slope of the plot. The values obtained from Langmuir adsorption isotherm (Table 3) showed high regression correlation coefficients $\left(\mathrm{R}^{2}\right) \quad 0.859$ indicating the fitness of model for the biosorption of Mn(II) ions was taken place at the functional groups/binding sites available on the surface of the algal biomass which is regarded as monolayer biosorption. Also $b$ value $48.52(\mathrm{~L} / \mathrm{mg})$ and maximum capacity (qmax) $21.80 \mathrm{mg} / \mathrm{g}$ as revealed from the Langmuir isotherm defines the total capacity of the biosorbent for biosorption of $\mathrm{Mn}$ (II) ions by the alga.

The Freundlich model (Freundlich, 1906) was also applied to estimate the adsorption intensity of the adsorbent towards the sorbate. This theorem considers multi-layers adsorption on the sorbent surface. This model is represented by the equation given below:

$$
q_{e}=K f C_{e}^{1 / n}
$$

Where, $K_{f}$ is the Freundlich empirical constant relative to sorption capacity, $C_{e}$ is the equilibrium concentration of metal ion in solution and $1 / n$ is the empirical constant relative sorption intensity. The values of the above Freundlich parameters were derived from the intercept and slope of a linear plot of " $\log q_{e}$ " versus " $\log C_{e}$ " (Fig. 8). The high values of Freundlich empirical constant relative to sorption capacity (Kf) 89.94 and empirical constant relative sorption intensity (n) 1.75 along with regression coefficient $\left(R^{2}\right) 0.761$ showed high feasibility of Mn (II) ions adsorption on the algal surface (Table 3).

Based on the comparison with $\mathrm{R}^{2}$ values obtained from both model, the equilibrium data was found to be fitted well to the Langmuir model rather than Freundlich model and also indicates the applicability of this metal ion-dried algal system for removal of Mn(II) ions in a monolayer biosorption as well as heterogenous surface conditions (Kiran et al., 2007; Pahlvanzadeh et al., 2010).

Thus, present chlorophycean green filamentous alga $S$. verrucosa was found to show better biosorption capacity $(40.66 \mathrm{mg} / \mathrm{g})$ for the removal of Mn(II) ions. The present study seems to agree with the trend shown by similar biosorption studies previously conducted for heavy metals and other cations by using green filamentous alga S. verrucosa (Gupta et al., 2001; Shuja and Azzizullah, 2006) and Spirogyra Species (Gupta et al., 2006; Bishnoi et al., 2007; Gupta and Rastogi, 2008; Matei et al., 2015).

\section{Conclusion}

The purpose of the present study was to find out the biosorption capacity of filamentous green alga, $S$. verrucosa collected from Manganese mine water. The dead algal biomass was taken under investigation for the removal of observed Manganese concentrations in mine water and to propose low cost eco-friendly biosorbents for mine water treatment. The findings were based on biosorption capacity, equilibrium modeling and kinetic studies. Experiments were carried out in order to examine the effect of initial solution $\mathrm{pH}$, temperature, initial metal ion concentration, biosorbent dosage and contact time. The values of these parameters obtained on performing batch mode studies revealed that $\mathrm{pH} 5$, temperature $30^{\circ} \mathrm{C}$, biosorbent quantity $1.0 \mathrm{gm} / \mathrm{l}$, contact time $120 \mathrm{~min}$. and initial metal ion concentration $50 \mathrm{mg} / \mathrm{l}$ were the optimum requirement for the biosorption of Mn(II) ions.

The biosorption kinetic and isotherm modeling applied to the equilibrium data for biosorption of Mn(II) ions onto alga reveals the fitness of the pseudo-second-order rate expression $\left(\mathrm{R}^{2}=0.994\right)$ as well as the suitability of Langmuir $\left(\mathrm{R}^{2}=0.859\right)$ and Freundlich $\left(\mathrm{R}^{2}=0.761\right)$ isotherm models with an indication of the applicability of this metal ion-dried algal system for removal of Mn(II) ions in a monolayer biosorption as well as heterogenous surface conditions. However, comparatively biosorption equilibrium was better described by Langmuir isotherm model with monolayer biosorption capacity of S.verrucosa biomass $21.80 \mathrm{mg} / \mathrm{g}$. Also, the maximum removal $40.66 \mathrm{mg} / \mathrm{g}(80.20 \%)$ of $\mathrm{Mn}(\mathrm{II})$ ion by alga under optimized conditions.

Thus, the present study concludes that $S$. verrucosa could be employed as a low-cost and eco-friendly biosorbent as a substitute to the expensive methods used at present for the removal of Mn (II) ions from acidic mine water (AMD) with special emphasis on manganese mine water. This may also help in the development of subsequent eco-friendly mine water treatment technologies in the application of biosorption at industrial scale.

\section{Competing interests}

Author declares that they do not have any competing interests.

\section{Authors' contributions}

SRB and PBN conceived the idea. SRB designed the experiments, performed the survey of mines, collected 
samples, analyzed the data and interpreted the results. SRB wrote the manuscript, PBN finalized and approved the final content of the manuscript. Both SRB and PBN commented on and revised the manuscript.

\section{Acknowledgement}

Authors are thankful to MOIL (Manganese Ore India Limited) Nagpur Region for granting permission to visit and survey the Manganese mines of Nagpur District, Vidarbha Region.

\section{References}

Ahalya, N., Ramachandra, T.V., Kanamadi, R.D. 2003. Biosorption of heavy metals. Research. Journal of. Chemistry and Environment. 7: 71-78

Aksu, Z., Egretli, G. and Kutsal, T. 1998. A comparative study of $\mathrm{Cu}$ (II) biosorption on Ca-alginate agarose and immobilized Chlorella vulgaris in a packed bed column. Process Biochem., 33(4): 393400.doi:10.1016/s0032-9592(98)00002-8.

Arica, M.Y., Kacar, Y., Genc, O. 2001. Entrapment of white-rot fungus Trametes versicolor in $\mathrm{Ca}$ alginate beads: Preparation and biosorption kinetic analysis for cadmium removal from an aqueous solution. Journal of Bioresource Technology,80 (2), 121-129.doi:10.1016/s09608524(01)00084.

Aydin, H., Buluta, Y. and Yerlikaya, C. 2008. Removal of copper (II) from aqueous solution by adsorption onto low-cost adsorbents, J. Environ. Manage., 87(1):37-45.doi:10.1016/jenvman.2007.01.005.

Bailey, J.E., Olin, T.J., Bricka, R.M. and Adrian, D.D. 1999. Areview of potentially low-cost sorbents for heavy metals. Water research.,33(11): 24692479.doi:10.1016/s0043-1354(98)00475-8.

Bansod, S.R. and Nandkar,P.B. 2015. Physiological effects of mining contaminants on algae with special reference to heavy metal toxicity. International Journal of Researches in Biosciences, Agriculture and Technology, 3:43-55.

Bishnoi, N.R., Kumar, R., Kumar, S. and Rani, S. 2007. Biosorption of $\mathrm{Cr}$ (III) from aqueous solution using algal biomass of Spirogyra spp., J. Hazard. Mater. $\quad 145(1-2): \quad 142$

147.doi:10.1016/j.jhazmat.2006.10.093.

Brenner, F.J. 2001. Use of Constructed Wetlands for Acid Mine Drainage Abatement and Stream Restoration. Wat. Sci. Technol., 44, 11-12, 449.doi:10.1061/40569 (2001)495.

Crist, H.R., Oberholser, K., Shank, N. and Nguyen, M. 1981. Nature of bonding between metallic ions and algal cell walls, Environ.Sci.Technol. 15(10),1212-1217. doi:10.1021/es0092a010.

Deng, L.P., Zhu, X., Wang, X. and Su, Y. 2007. Biosorption of copper (II) from aqueous solutions by green alga Cladophora fascicularis, Biodegradation. 18(4): 393-402.doi:10.1007/s10532-006-9074-6.

Deo, N. and Ali, M., 1993. Dye adsorption by a newlowcost material: Congored. Indian J. Environ. Prot., 12: 828

Donmez, G. and Aksu, Z. 2002. Removal of Chromium (IV) from saline wastewaters by Dunaliella species. Process Biochem., 38(5), 751762.doi:10.1016/s0032-9592 (02) 00204.
Dundar, M., Nuhoglu, C. and Nuhoglu, Y. 2008. Adsorption of $\mathrm{Cu}$ (II) ions onto the litter of natural trembling poplar forest. Journal of Hazardous Materials 151(1): 8695.doi:10.1016/j.jhazmat.2007.05.055.

Dursun, A.Y. 2006. "A comparative study on determination of the equilibrium, kinetic and thermodynamic parameters of biosorption of copper(II) and lead(II) ions onto pretreated Aspergillus niger," Biochem. Eng. J., 28(2), 187195. doi:10.1016/j.bej.2005.11.003.

Freundlich, H. 1906. Adsorption in solution. J. Phys. Chem., 57: 385-470.

Guiry, M.D. and Guiry, G.M. 2014. Algae base. Word wide electronic publication, National University of Ireland, Galway. www.algaebase.org; searched on $10^{\text {th }}$ August 2014.

Gupta, V., Agarwal, J., Sharma, S. 2008. Adsorption Analysis of Mn(VII) from Aqueous Medium by Natural Polymer Chitin and Chitosan. Asian J.of Chem.,20(8): 6195-98.

Gupta, V.K. and Rastogi, A. 2008. Sorption and desorption studies of chromium (VI) from nonviable Cyanobacterium, Nostoc muscorum biomass. J. Hazard. Mater., 154(1-3): 347354.doi:10.1016/j.jhazmzt.2007.10.032.

Gupta, V.K., A.K. Shrivastava. N. Jain 2001. Biosorption of chromium (VI) from aqueous solution by green algae Spirogyra species. Water Research. 35(17): 4079-4085.doi:10.1016/s0043-1354 (01) 00138-5.

Gupta, V.K., Rastogi, A., Saini, V.K. and Jain, N. 2006. Biosorption of copper (II) from aqueous solutions by Spirogyra species. Journal of Colloid and Interface Science, 296(1): 5963.doi:10.1016/j.jcis.2005.08.033.

Han, X., Wong Y.S. and Tam, N.F.Y. 2006. Surface complexation mechanism and modeling in $\mathrm{Cr}$ (III) biosorption by a microalgal isolate, Chlorella miniata, J. Colloid Interface Sci., 303(2): 365371.doi:10.1016/j.jcis. 2006.08.028.

Ho, Y.S. and McKay, G. 1999. Pseudo-second order model for sorption process. Process Biochem., 34(5): 451465.doi:10.1016/s0032-9592(98)00112-5.

Kiran, B., Kaushik, A. and Kaushik, C.P. 2007. Biosorption of $\mathrm{Cr}$ (VI) by native isolate of Lyngbya putealis(HH-15) in the presence of salts. J. Hazard. Mater., 141(3), 662-667.doi:10.1016/j.jhazmat. 2006.07.026.

Kratochvil, D. and Volesky, B. 1998. Advances in biosorption of heavy metals. Trends in Biotechnology., 16(7): 291-300.doi:10.1016/s01677799(98) 01218-9.

Langmuir, I. 1918. The adsorption of gases on plane surface of glass, mica and platinum. J. Am. Chem. Soc., 40(9): 1361-1403.doi:10.1021/ja02242a004.

Mashitah, M.D., Yus Azila, Y. and Bhatia, S. 2008. Biosorption of Cadmium (II) ions by immobilized cells of Pycnoporus sanguineus from aqueous solution. Bioresource Technology., 99(11): 47424748.doi:10.1016/j.biortech.2007.09.062.

Matei, G.M., Kiptoo, J.K., Oyaro, N. and Onditi, A.O. 2015. Biosorption of selected heavy metals by green algae, Spirogyra species and its potential as a pollution Biomonitor. Chemistry and Materials Research, 7 (7), 42-52. 
Matheickal, J.T. and Yu, Q. 1996. Biosorption of lead from aqueous solutions by marine alga Eklonia radiate. Water Sci.Technol.34(9): 17.doi:10.1016/s0273-1223(96) 00780-9.

Modis, K., Adam, K., Panagopoulas, K and Kontopulos, A. 1998. Development and validation of a geostatistical model for prediction of acid mine drainage in underground sulphide mines. Trans. Instn. Min. Metall., sect A, pp 102-107.

Mohan, D. and Chander, S. 2001. Single Component and Multi-Component Adsorption of Metal Ions by Activated Carbons. Coll. Surf. Physico. Eng. Aspects, 177(2-3), 183-196.doi:10.1016/s09277757(00) 00670-1.

Moreno, N., Querol, X., Ayora, C., Alastuey, A., Fernandez-Pereira, C. and Janssen-Jurkovicova, M. 2001.Potential Environmental Applications of Pure Zeolitic Material Synthesized from Fly Ash. J. Environ. Eng.-ASCE, 127 (11) 9941002.doi:10.1061/(asce) 0733-9372 (2001) 127:11(994).

Morgan, B.E., Loewenthal,R.E. and Lahav, O. 2004. Fundamental Study of a One-Step Ambient Temperature Ferrite Process for Treatmentof Acid Mine Drainage Waters. Wat. SA, 27(2), 277. doi:10.4314/wsa.v27i2.5001.

Onyancha, D., Mavura, W., Ngila, J.C., Ongoma, P., and Chacha, J. 2008. Studies of chromium removal from tannery wastewaters by algae biosorbents, Spirogyra condensata and Rhizoclonium hieroglyphicum. J. Hazard. Mater., 158(2-3): 605614.doi:10.1016/j.jhazmat. 2008.02.043.

Pahlvanzadeh, H., Keshtkar, A.R., Safdari, J. and Abadi, Z. 2010. Biosorption of nickel (II) from aqueous solution by brown algae: Equilibrium, dynamic and thermodynamic studies. J. Hazard. Mater., 175 (1-3): 304-310.doi:10.1016/j.jhazmzt. 2009.10.004.

Park, D. Yun, Y. S. and Park, J. M. 2005. Use of dead fungal biomass for the detoxification of hexavalent chromium: Screening and kinetics. Process Biochem., 40(7): 25592565.doi:10.1016/j.procbio.2004.12.002.

Romera, E., Gonzalez, F., Ballester, A., Blazquez, M.L. and Munoz, J.A. 2006. Biosorption with algae: A Statistical Review. J. Crit. Rev. Biotechnol., 26(4): 223-235.doi:10.1080/07388550600972153.
Saha, U.K., Taniguchi, S. and Sakurai, K. 2002. Simultaneous adsorption of cadmium, zinc, and lead on hydroxyalumium- and hydoroxyaluminosilica temontmorillinite complexes. Soil Sci. Soc. Am. J., 66(1): 117128.doi:10.2136/sssaj2002.0117.

Sandau, E., Sandau, P., Pulz, O. and Zimmermann, M. 1996. Heavy metal sorption by marine algae and algal byproducts. Acta Biotechnol. 16(2-3): 103-119.doi:10.1002/abio.370160203.

Shen, J.C. and Duvnjak, Z. 2004. Effects of temperature and $\mathrm{pH}$ on adsorption isotherms for cupric and cadmium ions in their single and binary solutions using corncob particles as adsorbent, Sep. Sci Technol.39(13): 3023 3041.doi:10.1081/ss-200030335.

Sheng, P.X., Ting, Y.P., Chen P.J. and Hong, L. 2004. Sorption of lead, copper, cadmium, zinc, and nickel by marine algal biomass: characterization of biosorptive capacity and investigation of mechanisms, J. Colloids Interf. Sci. 275(1): 131141.doi:10.1016/j.jcis.2004.01.036.

Shuja, A. and Azizullah. 2006. Effects of biomass concentration on the biosorption of Chromium by Spirogyra sp. Biologia, Pakistan. 52: 01-06.

Tunali, S., Akar, T., Ozcan, A. S. and Kiran, I. 2006. Equilibrium and kinetics of biosorption of lead (II) from aqueous solutions by Cephalosporium aphidicola. Sep. Purif. Technol., 47(3): 105 112.doi:10.1016/j.seppur.2005.06.009.

Volesky, B. 2001. Detoxification of metal-bearing effluents: Biosorption for the next century. Hydrometallurgy, 59(2-3): 203216.doi:10.1016/s0304-386x(00) 00160-2.

Volesky, B. 2003. Sorption and Biosorption. BVSorbex Inc, St. Lambert, Quebec, Canadá. p. 316.

Volesky, B. 2007. Biosorption and me, Water Res. 41(18): 4017 - 4029.doi:10.1016/j.watres.2007.05.062.

Wang, H.L. and Chen, C. 2006. Biosorption of heavy metals by Saccharomyces cerevisiae: A review,

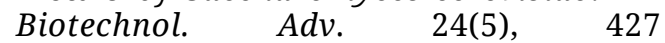
451.doi:10.1016/j.biotechadv.2006.03.001. 